\title{
Japan's Approach to Asia Pacific Economic COOPERATION
}

\begin{abstract}
Since emerging as a leading industrial economy, Japan has played an important role in promoting Asia Pacific economic cooperation. Japan has been instrumental in every major initiative in economic cooperation in the region over the past three decades, including the Asia Pacific Economic Cooperation (APEC) forum launched in 1989. Japan's commitment to free trade, reinforced by its own experience of discriminatory trade policies in the immediate postwar period, has made it a strong advocate of the principle of 'open regionalism' on which APEC is founded. Commitment to this principle has provided the basis for a process of unilateral liberalisation of trade, including agreed time frames, which allows the developing economies of the Asia Pacific region to progress towards free trade in a flexible manner and provides some protection against 'free riders'. The strength of this commitment will assist member economies to counter pressure for preferential trading arrangements and facilitate the extension of free trade to sectors which involve cooperation with economies outside the Asia Pacific region.
\end{abstract}

\section{Introduction}

While developments over the past year have raised many questions about the immediate prospects for East Asia's economic growth, the force of East Asian industrialisation has already transformed the contours of world economic power and influence (Drysdale and Elek, 1997). Japan was at the leading edge of East Asian industrialisation. In the postwar period, Japan's economy emerged to join the same league as the industrial economies of North America and Europe. The new role that Japan began to assume more clearly in the 1980s was defined in a pluralist structure of economic power, encompassing the effective representation of broader Asia Pacific and global interests, as well as those of the United States and Europe (Funabashi, 1995, Ch. 9).

Strong commitment to these regional and global goals has provided the stimulus for every major initiative for economic cooperation in the Asia Pacific region for more than 30

This paper draws on work completed recently with Andrew Elek and Hadi Soesastro ('Open Regionalism: The Nature of Asia Pacific Integration'), and David Vines and Brett House ('East Asia and Europe: A Shared Global Agenda?'). Many of the ideas and words are property shared with these colleagues. The argument in this paper is elaborated in Drysdale (1997). I am grateful to Ross Garnaut for his critical and helpful comments. I alone am responsible for the final shape of the argument. 
years, from the establishment of the Pacific Basin Economic Council and the Pacific Trade and Development conference series, through to the foundation of the Pacific Economic Cooperation Council (PECC) and the APEC forums. In all of these initiatives Japan played a crucial role, engaging the Association of South East Asian Nations countries and winning the support of the United States for the PECC and later the APEC initiative (Drysdale, 1988; Terada, 1998).

The establishment of APEC was part of the global response to the need for regional structures in the Asia Pacific, notable for their paucity compared with those in the Atlantic. Asia Pacific community-building was needed to cope with the realities of growing economic interdependence (APEC, 1993), and to allow Asia Pacific governments to contribute to collective leadership to shape a new global order following the end of the Cold War (Funabashi, 1997, Ch. 9; Drysdale, 1991). For these reasons, Japan has nurtured the APEC process, 'a novel experiment in regionalism with global objectives' (Drysdale and Elek, 1997, p. 4).

\section{Central principles}

At the core of the APEC philosophy is the idea of 'open regionalism' (Funabashi, 1995, p. 3). From its beginnings, APEC 'was not to be an economic bloc or legally bound free trade area like the European Community or the North American Free Trade Agreement (NAFTA)'; rather, APEC 'sought to realise a vision of global free trade, driven by the liberalisation of the Asia Pacific region's dynamic economies' (Funabashi, 1995, p. 3).

The objective of promoting economic consultation and cooperation among Asia Pacific governments was essentially a conservative one, to preserve the conditions needed to sustain the positive trends of rising prosperity and the productive integration of the region's economies (Garnaut, 1996, Ch. 1). Hence, APEC was born in 1989 out of deep concerns shared by East Asian and Western Pacific economies about the fate of the global trade regime and the slow progress of multilateral trade negotiations in the Uruguay Round during the 1980s.

Japan and the East Asian countries understood their stake in the strength and continuity of an open trading system, based upon the principle of nondiscrimination in trade embedded in Article 1 of the General Agreement on Tariffs and Trade. This was why the idea of open regionalism came to define the approach to the development of APEC and Asia Pacific integration from its beginnings. 
The idea of open regionalism is deeply rooted in the history of Japan's support for APEC (Terada, 1998). Japan's experience of discriminatory trade policies during the interwar period is seared into Japanese memory, and nondiscrimination in trade policy stands out as the central guiding principle of Japan's postwar international trade diplomacy. Takeo Miki, one of the early advocates of Asia Pacific economic cooperation, declared that 'it would be an act of suicide on our part to create an exclusive and closed trading bloc in the Pacific area' (Miki, 1968). A little over a decade later, the Ohira Study Group concluded that:

a regionalism that is open to the world, not one that is exclusive and closed, is the first characteristic of our concept ... a regional community without a perspective for a global community has no possibility of development and prosperity' (Japan Pacific Cooperation Study Group, 1980, p. 19).

These ideas were first given precision in English at the Pacific Community Seminar convened by Sir John Crawford at the initiative of Prime Ministers Ohira of Japan and Fraser of Australia at the Australian National University in September 1980 (Garnaut, 1996, p. 6). They became entrenched through the work of PECC after 1980 and were the intellectual foundation on which APEC was launched in Canberra in November 1989 (Crawford and Seow, 1981; Drysdale, Elek and Soesastro, 1998).

\section{Precept to practice}

APEC's agenda has evolved around giving substance to the idea of open regionalism. The APEC meetings held in Seattle in 1993 elevated the process of cooperation to the highest level of government. At the initiative of US President Clinton, an informal APEC leaders meeting was held in conjunction with the established ministerial meetings. The leaders issued an Economic Vision Statement which contained three elements. The first was an affirmation of the goal of reaching an open multilateral trading system and the determination of Asia Pacific leaders to take steps to produce the strongest possible outcome in the Uruguay Round (APEC, 1993).

The APEC leaders meeting the following year, held in Bogor, Indonesia, produced the Bogor Declaration of Common Resolve, which set the goals of achieving free and open trade and investment in the region by 2010 for developed member economies and 2020 for 
developing members (APEC, 1994). The commitment by leaders to achieve free and open trade by a certain date was an important milestone in APEC's development.

In spite of the principles set out in the Bogor declaration, there remained some ambiguities about the modality for achieving the APEC goal of free and open trade and investment in the region. These arose in proposals, including those put forward by the APEC Eminent Persons Group (Eminent Persons Group, 1994), which amounted to advocacy of a process of negotiated liberalisation among APEC members along the lines of a conventional free trade area, whose benefits could be extended to non-members only on a mutually reciprocated basis and in a way that would eliminate the problem of 'free riding', either within APEC itself or by non-members, notably European countries. The task of clarifying these issues rested with Japan, as the chair of APEC, in 1995.

APEC formally espoused open regionalism at its Osaka meetings in 1995. The Osaka Action Agenda was premised on the voluntary nature of the APEC process, an essential corollary of the idea of open regionalism (APEC, 1995). APEC members' commitment to the unilateral liberalisation of barriers to trade and investment is a necessary condition of open regionalism. Efforts to achieve such liberalisation are not seen as concessions for exchange in a negotiating process, but their collective effect (concerted unilateral liberalisation) reinforces regional trade liberalisation, consistently with Article 1 of the World Trade Organisation (WTO) and without requiring an Article 24 style discriminatory agreement (Drysdale, Elek and Soesastro, 1998).

Equally important, in the context of Asia Pacific community building, is the sense of comfort that this modality provides to APEC member economies, by allowing flexibility in the implementation of liberalisation commitments not based on uniformly negotiated schedules. APEC's trade liberalisation and facilitation agenda is adopted and implemented by the decisions of individual governments. Each member's liberalisation program is entered into voluntarily, in accordance with common guidelines for APEC cooperation adopted by consensus within the APEC process. Unilateral efforts are reviewed and monitored within APEC. As agreed in Osaka, members' Individual Action Plans cover trade liberalisation and trade and investment facilitation measures. In addition, Collective Action Plans raise the possibility of non-discriminatory sectoral liberalisation in sectors of special interest to APEC members - an option that was taken up at the Vancouver APEC meetings of November 1997. In Manila, APEC members also laid the foundation for the adoption of the Information 
Technology Agreement at the WTO Ministerial Meetings held in Singapore in late 1996 and subsequently (APEC, 1996).

In brief, there are three reasons why Japan and other Western Pacific countries have eschewed discrimination in developing Asia Pacific regional cooperation (Garnaut, 1996). First, the trading interests of East Asian and Pacific economies extend beyond APEC, including to Europe. A conventional free trade area strategy towards liberalisation would deter internationally-oriented reform in the region's developing economies, and introduce tension into relations with neighbours and major partners outside the region. Second, trade discrimination involves the unnecessary cost of trade diversion, complicated in the Asia Pacific by the likelihood of associated high political costs both within and outside the region (Garnaut and Drysdale, 1994, Ch. 5). Third, there is the sheer impracticability of undertaking regional trade liberalisation in such a diverse region via a conventional discriminatory free trade area of the kind sanctioned by the WTO - the most likely outcome would be a 'dirty bloc', in which there would be backsliding into partial preferential liberalisation, with various alliances of players picking and choosing the sectors to be liberalised, at various times (Drysdale, Vines and House, 1998, p. 7).

APEC has already become more than just a loose community of like-minded economies encouraging each other in a process of unilateral trade and investment liberalisation. It now provides the structure under which trade, technical cooperation, financial cooperation and, to a lesser extent, political tensions within the Asia Pacific region are managed.

\section{Conflicting paradigms across the Pacific}

APEC has special potential to be helpful in trans-Pacific relations. The tendency of the United States to conduct aspects of its trade relations bilaterally, and to seek bilateral reciprocity in its trade negotiations, is widely recognised. It is also understandable. For a hegemonic power - which the United States still is - there is a natural temptation to use muscle to force market opening (in the name of both self-interest and the general good). APEC has usefully provided a forum in which tensions between the United States and Japan, resulting from such actions by the United States, can be diffused and calmed. The APEC Summit in Manila also provided a congenial setting for presidential talks aiming to set United States-China relations on a more productive course. APEC has also established its worth in managing trans-Pacific tensions by serving as a vehicle for China's liberalisation agenda and supporting China's entry 
into the WTO. In 1997, APEC was also effective in terms of managing the regional financial crisis while keeping the trade liberalisation agenda on track.

Yet, during the last 15 years, there have been developments in US trade diplomacy that are potentially less benign for the prospects of open regionalism in APEC. These developments were born of US impatience with the process of multilateral negotiation, US frustration concerning its large bilateral relationships, such as those with Japan and Europe, and the challenge presented by the single-market initiative in the European Union.

Whether or not the US display of interest in preferential trade arrangements was initially largely tactical, regionalism has taken on a life of its own among US policymakers (Saxonhouse, 1997, p. 2). For example, it is an active issue in the consideration of a new 'fast track' negotiating authority for the US administration (Bergsten, 1997).

This is the US policy context in which APEC was launched. It is worth remembering that it was also the policy context in which Malaysia's Prime Minister Mahathir first put forward the idea of an East Asian Economic Caucus - to be, among other things, a tactical defence against North American regionalism. Of more relevance here, it is also the policy context in which a number of Americans, both within and outside of government, have been eager to maintain a preferential trading arrangement option for APEC (Saxonhouse, 1997, p. 4).

Bergsten (1997, p. 12) suggests a modification of open regionalism which qualifies its essential 'most favoured nation' feature. Under his scheme, APEC members would afford liberalisation only to those outsiders who offered similar liberalisation themselves. The requirement for reciprocal liberalisation has earned this approach the label 'reciprocitarianism'. The element of conditionality in Bergsten's formula means that the final choice of whether free trade or a free trade area was the endpoint of reform would be left until tariff reduction reached its final stages. Flamm and Lincoln (1997) echo Bergsten's critique of 'open regionalism', strictly defined, in a recent tract.

There are a number of vital objections to Bergsten's proposal (Drysdale, Vines and House, 1998, p. 19). Foremost, it is entirely unfeasible, in that there is no collective action mechanism by which this proposal could be carried through within the loose APEC grouping. Under Article 24 of the WTO, a formal agreement and an agreed timetable would be required. APEC has eschewed any moves in this direction.

APEC is not founded on an international agreement, nor does it possess any supranational authority that would allow it to take collective action of the kind presumed in such 
calculations. There is no prospect that this will change, given the approach of Japan, East Asian and Western Pacific members to Asia Pacific economic cooperation.

Drysdale, Elek and Soesastro (1998) propose that a positive response to APEC's lead on trade liberalisation, in which the European Union committed itself to eliminating all border barriers to trade and investment by 2020 , would resolve the 'free rider' problem, about which Bergsten worries, and set the stage for effective cooperation among both groups to achieve free and open trade and investment between them as well as within each region.

This relates to the question of whether voluntary cooperation will be adequate to deal with 'sensitive' sectors. Will it be possible to achieve deep liberalisation of agricultural trade in Northeast Asia, for example, without the pressures of hard negotiations and reciprocal concessions? The answer to this question may well be 'no'. But, consistently with the objectives and character of Asia Pacific economic cooperation, it is possible to plan ahead and deal with the liberalisation of some sensitive sectors in which there is also substantial extra-APEC interest within the WTO. This should begin a few years down the track, after the Uruguay Round commitments have been digested but before the APEC industrial economy free-trade deadline is reached in 2010. This strategy also presents a way of dealing with US concern about European 'free riding', and offers the opportunity to lock Europe into a liberalisation of trade barriers comparable to that taking place within APEC.

Further, there is the question of whether the APEC formula can accommodate the US lust for reciprocity from both other APEC countries and non APEC members. Over the next few years or so, this will not be a major problem. In practice, the United States will itself largely 'free ride' within APEC, as international liberalisation and reform continue to have most effect in East Asia and the Western Pacific (Garnaut, 1996, Ch. 1). This was reflected in the minimalist Individual Action Plan presented by the United States in Manila. The United States can best liberalise its remaining border measures in the context of broader WTO negotiations - perhaps during the Millennium Round advocated by European Commission Vice President Sir Leon Brittan.

These reservations do not, in any way, suggest that APEC is simply a holding operation. Quite the reverse: they underline the importance of APEC in providing a vehicle for active trade and investment liberalisation when this is an urgent priority for the industrialising economies of East Asia and other economies in the Western Pacific, so that they do not have to hold back until the next comprehensive WTO round of negotiations delivers an opportunity for policy progress. 


\section{Conclusion}

The defining concept of Asia Pacific cooperation is the Japanese and Australian idea of 'open regionalism'. Properly understood, as it has been conceived and implemented within APEC, it encompasses 'integrative processes that contain no element of exclusion against outsiders' (Garnaut and Drysdale, 1994, p. 2). It underpins the agenda for liberalisation in APEC, with the first principles of the WTO as its reference point and the WTO as its ultimate agent. It collides with support, in the United States and elsewhere, for discriminatory regionalism. The resolution of this clash is still being played out in the theatre of Asia Pacific diplomacy (Drysdale, 1997).

As Saxonhouse (1997, p. 11) observes, the outcome of fifteen years of US flirtation with regionalist trade policies could possibly be a network of preferential trade arrangements centred on the United States, competing with a similar set of arrangements centred on the European Union. Such an outcome would be politically dangerous and costly in economic terms.

The position of Japan and East Asia in this equation is crucial. If the role of Japan and East Asia in APEC is any guide, a more likely outcome could be a strengthened multilateral system based on the WTO. East Asia, through the Asia Europe Meeting process, has also strategically engaged Europe as a balancing presence. Europe is a willing partner - despite contradictions in its own trade diplomacy towards its East and its South - because of both its interest in the growing economic opportunities in East Asia and its own concerns about US bilateralism.

The United States, in its hitherto unsuccessful attempt to secure a 'fast track', has recently reiterated its interest in preferential trading arrangements with Australia, Chile, New Zealand and Singapore. Australia, at least, will again reject the overture, as a potentially disastrous diversion from its strategic interests in East Asia.

The 'Realpolitik' in trade policy that has been a raging fashion in Washington is as likely to run into the sand as conquer the Pacific. If it does, it will be because of the strength and steadiness of Japan and the East Asian economies in holding to their goal of open regionalism in Asia and the Pacific and defending their abiding interest in the health of the WTO system. 
No. 281 July 1998

\section{References}

Asia Pacific Economic Cooperation forum (APEC) (1993) Economic Vision Statement, Seattle, November.

- - (1994) Bogor Declaration of Common Resolve, Second APEC Economic Leaders Meeting, Bogor, November.

- - (1995) Osaka Action Agenda: Implementation of the Bogor Declaration, Third APEC Economic Leaders Meeting, Osaka, November.

- - (1996) Manila Action Plan for APEC, Ministerial-level meeting, Manila, November.

- - (1997) Leaders Declaration, Vancouver, November.

Bergsten, C. Fred (1997) 'Open Regionalism', The World Economy.

Crawford, J.G. and Greg Seow (eds) (1981) Pacific Economic Cooperation: Suggestions for Action, paper prepared for the Pacific Community Seminar, Petaling Jaya: Heinemann Asia.

Drysdale, Peter, (1988) International Economic Pluralism: Economic Policy in East Asia and the Pacific, New York: Columbia University Press and Sydney: Allen and Unwin.

- - (1991) 'Open Regionalism: A Key to East Asia's Economic Future?', Pacific Economic Papers 197, Canberra: Australia-Japan Research Centre.

- - (1997) 'APEC and the WTO: Complementary or Competing?', paper presented to the Institute of Southeast Asian Studies APEC Roundtable, Singapore, 6 August.

- - and Andrew Elek (1997) 'APEC: Community-building in East Asia and the Pacific', in Donald C. Hellman and Kenneth B. Pyle (eds), From APEC to Xanadu, Seattle: National Bureau of Asian Research and New York: M.E. Sharpe, pp. 37-49.

- - and Andrew Elek and Hadi Soesastro (1998) 'Open Regionalism: The Nature of Asia Pacific Integration', in Peter Drysdale and David Vines (eds) (1998) Europe, East Asia and APEC: a shared global agenda?, Cambridge: Cambridge University Press.

- - and Ross Garnaut (1989) 'A Pacific Free Trade Area?' in Jeff J. Schott (ed.), More Free Trade Areas?: Free Trade Areas and US Trade Policy, Washington DC: Institute for International Economics, pp. 217-54.

- - and Ross Garnaut (1994) 'Principles of Pacific Economic Integration', in Ross Garnaut and Peter Drysdale (eds), Asia Pacific Regionalism: Readings in International Economic Relations, Sydney: HarperEducational [pp. ?].

- - and David Vines (eds) (1998) Europe, East Asia and APEC: a shared global agenda?, Cambridge: Cambridge University Press.

- - and David Vines and Brett House (1998) 'Europe and East Asia: A Shared Global Agenda?' in Peter Drysdale and David Vines (eds) (1998) Europe, East Asia and APEC: a shared global agenda?, Cambridge: Cambridge University Press.

Eminent Persons Group (1994) Achieving the APEC Vision: Second Report of the Eminent Persons Group, Singapore: APEC.

Flamm, Kenneth and Edward Lincoln (1997) 'Time to Reinvent APEC', Policy Briefs, No. 26, November, Washington DC: Brookings Institution.

Funabashi, Yoichi (1995), Asia Pacific Fusion: Japan's Role in APEC, Washington DC: Institute of International Economics. 
Garnaut, Ross (1996) Open Regionalism and Trade Liberalisation, Singapore: Institute of South East Asian Studies and Sydney: Allen and Unwin.

- - and Peter Drysdale (eds) (1994) Asia Pacific Regionalism: Readings in International Economic Relations, Sydney: HarperEducational.

Japan Pacific Cooperation Study Group (1980) Report on the Pacific Basin Cooperation Concept, Tokyo: Prime Minister's Office.

Miki, Takeo (1968) 'Japan's Foreign Policy', speech delivered at the Australian National University, 29 July.

Saxonhouse, Gary R. (1997) 'Regional Initiatives and US Trade Policy in Asia', Asian-Pacific Economic Literature, Vol. 11, No. 2, November.

Terada, Takashi (1998) ‘The Origins of Japan's APEC Policy: Foreign Minister Takeo Miki’s Asia Pacific Policy and Current Implications', The Pacific Review (forthcoming).

\section{Previous Pacific Economic Papers}

280 The politics of telecommunications reform in Japan

Hidetaka Yoshimatsu, June 1998

279 Sustainability of growth in the Korean manufacturing sector Chang-Soo Lee, May 1998

278 Export performance of environmentally sensitive goods: a global perspective Xinpeng $X u$, April 1998

277 Modelling manufactured exports: evidence for Asian newly industrialising economies

Francis In, Pasquale Sgro and Jai-Hyung Yoon, March 1998

276 Laos in the ASEAN free trade area: trade, revenue and investment implications Jayant Menon, February 1998

275 Globalisation

Heinz Arndt, January 1998

274 The WTO and APEC: What role for China?

Stuart Harris, December 1997

273 The APEC air transport schedule

Christopher Findlay, November 1997

272 Japanese foreign direct investment in real estate 1985-1994

Roger Farrell, October 1997

271 China and East Asia trade policy volume 4: Trade reform and liberalisation in China

Yang Shengming, Zhong Chuanshui, Yongzheng Yang, Feng Lei, Yiping Huang, and Pei Changhong, September 1997 
270 The politics of economic reform in Japan

T.J. Pempel, Tony Warren, Aurelia George Mulgan, Hayden Lesbirel, Purnendra Jain and Keiko Tabusa, August 1997

269 Diplomatic strategies: the Pacific Islands and Japan Sandra Tarte, July 1997

268 Interest parity conditions as indicators of financial integration in East Asia Gordon de Brouwer, June 1997

267 Consensus in conflict: competing conceptual structures and the changing nature of Japanese politics in the postwar era Lindy Edwards, May 1997

266 The role of foreign pressure (gaiatsu) in Japan's agricultural trade liberalisation Aurelia George Mulgan, April 1997

265 Transformation in the political economy of China's economic relations with Japan in the era of reform Dong Dong Zhang, March 1997

264 Economic relations across the Strait: interdependence or dependence? Heather Smith and Stuart Harris, February 1997

263 Has Japan been 'opening up'?: empirical analytics of trade patterns Jayant Menon, January 1997

262 Postwar private consumption patterns of Japanese households: the role of consumer durables Atsushi Maki, December 1996

261 East Asia and Eastern Europe trade linkages and issues Jocelyn Horne, November 1996

260 National choice Wang Gungwu, October 1996

259 Australia's export performance in East Asia Peter Drysdale and Weiguo Lu, September 1996

258 Public infrastructure and regional economic development: evidence from China Weiguo Lu, August 1996

257 Regional variations in diets in Japan Paul Riethmuller and Ruth Stroppiana, July 1996

256 Japanese FDI in Australia in the 1990s: manufacturing, financial services and tourism

Stephen Nicholas, David Merrett, Greg Whitwell, William Purcell with Sue Kimberley, June 1996 
255 From Osaka to Subic: APEC's challenges for 1996 Andrew Elek, May 1996

254 NAFTA, the Americas, AFTA and CER: reinforcement or competition for APEC? Richard H. Snape, April 1996

253 Changes in East Asian food consumption: some implications for Australian irrigated agriculture

Philip Taylor and Christopher Findlay, March 1996

252 Behaviour of Pacific energy markets: the case of the coking coal trade with Japan Richard J. Koerner, February 1996

251 Intra-industry trade and the ASEAN free trade area Jayant Menon, January 1996

250 China and East Asia trade policy, volume 3:

China and the world trade system

Various authors, December 1995 (special volume)

249 China and East Asia trade policy, volume 2:

Regional economic integration and cooperation

Various authors, November 1995 (special volume)

248 China and East Asia trade policy, volume 1:

East Asia beyond the Uruguay Round

Various authors, October 1995 (special volume)

Annual subscription rate for twelve issues:

Individuals A $\$ 60.00$

Institutions $\mathrm{A} \$ 100.00$

\section{Cost for single issues:}

$\mathrm{A} \$ 15.00$

$\mathrm{A} \$ 10.00$ (Students)

All prices include postage

Available from: Publications Department

Australia-Japan Research Centre

Research School of Pacific and Asian Studies

The Australian National University

Canberra ACT 0200, Australia

Facsimile: (61 2) 62490767

Telephone:(612)62493780

Email:ajrcgen@ajrc.anu.edu.au 